\title{
KANDUNGAN FITOKIMIA DAN AKTIVITAS ANTIOKSIDAN EKSTRAK METANOL RUMPUT LAUT Kappaphycus alvarezii
}

\author{
Puji L. Lantah', Lita A.D.Y. Montolalu², Albert R. Reo \\ ${ }^{1)}$ Mahasiswa pada Program Studi Teknologi Hasil Perikanan FPIK Unsrat Manado \\ ${ }^{2)}$ Staf pengajar pada Program Studi Teknologi Hasil Perikanan FPIK Unsrat Manado
}

\begin{abstract}
The research about phytochemical content and antioxidant activity of seaweed Kappaphycus alvarezii methanolic extract has been done. The purpose of this research is to determine the phytochemical content and antioxidant activity of seaweed Kappaphycus alvarezii which extraction using methanol as solvent. Extraction has done with maseration using methanol solvent, phytochemical tests include alkaloid, flavonoid, saponin, triterpenoid, and steroid were determined using some reagents and antioxidant activity assay using DPPH (1,1-diphenyl-2-picrylhydrazyl). This research obtained phytochemical contents such as alkaloid, flavonoid, saponin, steroid and triterpenoid of Kappaphycus alvarezii methanolic extract was undetected and antioxidant activity of Kappaphycus alvarezii methanolic extract using DPPH method was very weak which $\mathrm{IC}_{50}>200 \mathrm{ppm}$ that is $163,819.99 \mathrm{ppm}$. Phytochemical content was not detected caused by sample preparation procedure, that is using seaweed obtained in dry condition, which is previously been exposed to heat and sunlight, the type of seaweed and the process of desalting is not optimal, thus affecting to antioxidant activity. This research obtained a very weak antioxidant activity presumably derived from unsaturated fatty acids that contained in seaweed Kappaphycus alvarezii.
\end{abstract}

Keyword: Kappaphycus alvarezii, phytochemical, antioxidant aktivity, DPPH.

\begin{abstract}
ABSTRAK
Penelitian tentang Kandungan Fitokimia dan Aktivitas Antioksidan Ekstrak Metanol Rumput Laut Kappaphycus alvarezii telah dilakukan. Tujuan penelitian ini dilakukan untuk menguji kandungan fitokimia dan aktivitas antioksidan rumput laut Kappaphycus alvarezii dengan ekstraksi menggunakan pelarut metanol. Ekstraksi dilakukan dengan cara maserasi dengan pelarut metanol, uji fitokimia yang meliputi alkaloid, flavonoid, saponin, triterpenoid dan steroid ditentukan dengan menggunakan beberapa pereaksi dan uji aktivitas antioksidan menggunakan metode DPPH (1-1-difenil-2-pikrilhidrazil). Pada penelitian ini diperoleh kandungan fitokimia berupa alkaloid, flavonoid, saponin, steroid dan triterpenoid pada ekstrak metanol Kappaphycus alvarezii tidak terdeteksi dan aktivitas antioksidan dengan metode DPPH pada rumput laut Kappaphycus alvarezii ekstrak metanol sangat lemah dimana $\mathrm{IC}_{50}>200 \mathrm{ppm}$ yakni 163.819,99 ppm. Tidak terdeteksinya kandungan fitokimia antara lain disebabkan oleh prosedur persiapan sampel, yakni menggunakan rumput laut yang diperoleh sudah dalam keadaan kering dimana sebelumnya telah terpapar panas dan sinar matahari, jenis rumput laut itu sendiri dan proses desalting yang tidak maksimal sehingga mempengaruhi aktivitas antioksidan. Penelitian ini memperoleh aktivitas antioksidan yang sangat lemah diduga berasal dari asam lemak tak jenuh yang terkandung dalam rumput laut Kappaphycus alvarezii.
\end{abstract}

Kata Kunci: Kappaphycus alvarezii, fitokimia, aktivitas antioksidan, DPPH.

\section{PENDAHULUAN}

Fenomena pangan fungsional telah melahirkan paradigma baru bagi perkembangan ilmu dan teknologi pangan, yaitu dilakukannya berbagai modifikasi produk olahan pangan menuju sifat fungsional. Pangan fungsional adalah pangan yang secara alamiah maupun telah melalui proses, mengandung satu atau lebih komponen bioaktif seperti fitokimia, asam lemak tak jenuh, serat dan lain-lain yang berdasarkan kajian-kajian ilmiah dianggap mempunyai fungsi-fungsi fisiologis tertentu yang bermanfaat bagi kesehatan antara lain memperkuat daya tahan tubuh, mengatur ritme kondisi fisik, memperlambat penuaan, dan membantu mencegah penyakit (Badan POM, 2001; Wijaya, 2002 dalam Suarni \& Yasin, 2011). Manfaat tersebut berasal dari komponen aktif yang terkandung dalam pangan fungsional tetapi tidak dikemas dalam bentuk kapsul, tablet, atau bubuk (Putranto, 2015).

Beberapa jenis rumput laut merupakan sumber potensial pangan fungsional yang dapat dimanfaatkan untuk kesehatan karena mengandung senyawa kimia yang mempunyai aktivitas 
biologis (zat bioaktif). Senyawa aktif biologis itu merupakan metabolit sekunder yang meliputi alkaloid, flavonoid, terpenoid, tannin, dan saponin. Kandungan senyawa metabolit sekunder dalam rumput laut dapat diketahui dengan suatu metode pendekatan yang dapat memberikan informasi adanya senyawa metabolit sekunder. Salah satu yang dapat digunakan adalah metode uji fitokimia (Setyowati, $d k k ., 2014$ ).

Kappaphycus alvarezii merupakan salah satu jenis rumput laut (alga) yang banyak dikembangkan di daerah tropis seperti Indonesia, khususnya di Sulawesi Utara. Rumput laut Kappaphycus alvarezii telah teridentifikasi dapat meningkatkan daya tahan tubuh, anti kanker, mencegah penuaan dini, menjaga kehalusan kulit. Selain itu, rumput laut ini juga teridentifikasi mengandung senyawa antioksidan (Seksi \& Serat, 2012). Dari manfaat-manfaat tersebut maka rumput laut Kappaphycus alvarezii sangat potensial dimanfaatkan sebagai pangan fungsional.

Penelitian tentang rumput laut Kappaphycus alvarezii masih banyak berfokus pada kandungan kappa karaginan. Untuk itu penelitian ini dilakukan berfokus pada kandungan fitokimia dan aktivitas antioksidan rumput laut Kappaphycus alvarezii ekstrak metanol khususnya yang berasal dari Sulawesi Utara, sehingga diperoleh informasi yang dapat menjadi data dasar dalam upaya pemanfaatan rumput laut sebagai sumber pangan fungsional dan antioksidan untuk obat dan industri makanan.

\section{METODOLOGI PENELITIAN}

\section{Tempat dan Waktu Penelitian}

Penelitian ini dilakukan selama 5 bulan, yakni bulan Februari-Juni 2017 di Lab. Pengendalian Mutu Hasil Perikanan, Lab. Biomolekuler dan Farmasitika Laut Fakultas Perikanan dan Ilmu Kelautan Universitas Sam Ratulangi Manado untuk proses ekstraksi. Untuk analisa fitokimia dan aktivitas antioksidan dengan metode DPPH dilakukan di Lab. Aplikasi Kimia dan Pelayanan Jurusan Kimia FMIPA Universitas Padjajaran Bandung dan Lab. Kimia Program Studi Farmasi FMIPA Universitas Sam Ratulangi.

\section{Alat dan Bahan}

Evaporator, neraca analitik, inkubator, pipet tetes, spektrofotometer UV-Vis, kertas saring Whatman no. 42, dan alat-alat gelas lainnya.
Bahan baku penelitian berupa Kappaphycus alvarezii kering yang didapat dari distributor rumput laut UD. Sumber Rejeki di Kelurahan Mahawu, Kecamatan Tuminting, Kota Manado. Bahan-bahan lain seperti metanol teknis, $\mathrm{H}_{2} \mathrm{SO}_{4}$, pereaksi dragendorff, pereaksi wegner, kloroform, $\mathrm{FeCl}_{3}$, anhidra asetat, $\mathrm{HCl} 2 \mathrm{~N}$, serbuk magnesium, metanol p.a, akuades, 1,1diphenyl-2-picrylhydrazil (DPPH), dan vit. C.

\section{Prosedur Penelitian \\ Prosedur Persiapan Sampel Kappaphycus alvarezii}

Rumput laut diperoleh dari UD. Sumber Rejeki di Kel. Mahawu, Kec. Tuminting, Kota Manado dalam keadaan kering kemudian ditimbang, dicuci, dikeringkan dan dipotong kecil-kecil (simplisia).

\section{Proses Ekstraksi}

Simplisia ditimbang sebanyak 350 gram lalu maserasi dengan metanol 1:4 (w/v) selama $3 \times 24$ jam pada suhu kamar hingga filtrat mendekati bening. Hasil maserasi kemudian disaring dengan kertas saring Whatman no. 42 sehingga dihasilkan filtrat dan residu.

Filtrat dievaporasi dengan vacuum rotary evaporator pada suhu $40^{\circ} \mathrm{C}$. Ekstrak kental hasil evaporasi kemudian dilakukan proses desalting dengan teknik dekantasi, yakni dengan cara mencampur ekstrak kental dengan metanol p.a kemudian garam akan mengendap. Lakukan berulang-ulang hingga warna putih yang menunjukkan adanya garam pada pelarut hilang. Ekstrak tersebut dievaporasi kembali menggunakan vacuum rotary evaporator pada suhu $40^{\circ} \mathrm{C}$. Ekstraksi sampel dilakukan dengan mengacu pada penelitian Faskalia \& Wibowo (2014) dan Suryaningrum $d k k$, (2006).

\section{Uji Rendemen (AOAC, 1995)}

Rendemen diperoleh dari perbandingan berat ekstrak dengan berat sampel awal. Persentase rendemen dari sampel dapat dihitung dengan menggunakan rumus:

$$
\% \text { rendemen }=\frac{\text { Bobot ekstrak }}{\text { Bobot sampel awal }} \times 100 \%
$$

\section{Analisis Fitokimia (Harborne, 1987) Uji flavonoid}

Timbang sampel lalu ekstraksi dengan metanol, saring dengan kapas dan dipindahkan ke tabung lain (ekstrak metanol). Untuk pengu- 
jian menggunakan pereaksi $\mathrm{HCl}$ pekat, ekstrak metanol sampel ditambahkan $\mathrm{HCl}$ pekat sebanyak 2 tetes. Kocok kuat ekstrak tersebut lalu tambahkan $\mathrm{Mg}$ serbuk dan kocok kuat sekali lagi. Sampel positif mengandung flavonoid dengan pereaksi $\mathrm{HCl}$ pekat apabila terdapat buihbuih dan larutan berubah menjadi warna jingga. Untuk pengujian digunakan pereaksi $\mathrm{H}_{2} \mathrm{SO}_{4} 2 \mathrm{~N}$, ekstrak metanol sampel ditambah 2 tetes $\mathrm{H}_{2} \mathrm{SO}_{4}$ $2 \mathrm{~N}$ lalu kocok kuat. Sampel positif mengandung flavonoid dengan menggunakan pereaksi $\mathrm{H}_{2} \mathrm{SO}_{4}$ $2 \mathrm{~N}$ bila terdapat perubahan warna kuning, merah atau cokelat yang sangat mencolok.

\section{Uji Alkaloid}

Timbang sampel kemudian ekstraksi dengan kloroform amoniakal. Saring dengan kapas dan pindahkan ke tabung A dan B. Pada masing-masing tabung A dan B tambahkan pereaksi Dragendorff dan pereaksi Wagner. Sampel pada tabung A positif mengandung alkaloid jika terdapat endapan berwarna kemerahan dan pada tabung B terdapat endapan kecokelatan.

\section{Uji Saponin}

Timbang sampel kemudian ekstraksi dengan kloroform amoniakal. Saring dengan kapas dan pindahkan ke tabung lain. Kocok kuat sampel tersebut dan diamkan selama 2 menit, kemudian tambahkan $\mathrm{HCl} 2 \mathrm{~N}$ sebanyak 2 tetes. Kocok kuat lagi dan lihat apakah terbentuk buih-buih setelah didiamkan selama 10 menit. Sampel positif mengandung saponin bila terdapat buih-buih dengan intensitas yang banyak dan konsisten selama 10 menit.

\section{Uji Triterpenoid dan Steroid}

Timbang sampel kemudian ekstraksi dengan etanol. Saring menggunakan kapas lalu panaskan hingga kering. Ekstraksi lagi dengan kloroform dan air (1:1). Ekstrak kloroform tersebut diteteskan pada plat tetes sebanyak 2 tetes dan biarkan sampai kering. Tambahkan asam sulfat pekat sebanyak 1 tetes dan asam asetat anhidrat sebanyak 1 tetes. Sampel positif mengandung triterpenoid apabila mengalami perubahan warna merah atau cokelat dan positif mengandung steroid apabila mengalami perubahan warna biru, ungu atau hijau.

\section{Uji Aktivitas Antioksidan dengan Metode DPPH (Blois, 1958)}

Buat larutan DPPH $4 \times 10^{-4} \mathrm{M}$ dan masukkan ke dalam vial dan tutup dengan rapat.
Lapisi permukaan vial dengan alumunium foil agar terhindar dari cahaya. Kemudian buat larutan sampel 1000 ppm yakni dengan melarutkan sampel dengan pelarut metanol.

Untuk pengujian sampel, masukkan berturut-turut larutan stock dan metanol sesuai dengan volume yang tertera pada tabel 1. Pada masing-masing tabung reaksi $(\mathrm{A}-\mathrm{H})$ dan tambahkan larutan DPPH sebanyak $1 \mathrm{ml}$ ke masing-masing tabung reaksi tersebut lalu biarkan selama 30 menit. Selanjutnya diukur menggunakan spektrometer UV-Vis dengan panjang gelombang $517 \mathrm{~nm}$. Kemampuan untuk meredam radikal bebas DPPH (inhibisi) dihitung dengan menggunakan persamaan:

$$
\% \mathrm{~h}=\frac{\mathrm{Ab}-\mathrm{As}}{\mathrm{Ab}} \times 100 \%
$$

$\% \mathrm{~h}=\%$ inhibisi (hambatan radikal bebas)

$\mathrm{Ab}=$ Absorbansi blanko

As = Absorbansi sampel

Nilai konsentrasi penghambatan radikal bebas sebanyak 50\% (IC50) dihitung dengan menggunakan persamaan regresi $\mathrm{y}=\mathrm{ax}+\mathrm{b}$.

\section{HASIL DAN PEMBAHASAN}

\section{Rendemen Ekstrak}

Rendemen rumput laut ekstrak metanol yang diperoleh adalah $0,034 \%$, dimana filtrat cair yang diperoleh adalah 4,2 liter dan setelah dievaporasi diperoleh berat sampel 12 gram. Nurhayati, dkk. (2009) dalam Romansyah (2012) menyatakan persentase rendemen yang rendah menunjukkan komponen bioaktif yang terkandung di dalamnya juga rendah dan sebaliknya. Penelitian yang dilakukan Suryaningrum, $d k k$. (2006) rumput laut segar yang kemudian dikeringkan mengalami penurunan persentase rendemen yang cukup tajam, yakni $5,79 \%$ menjadi $1,03 \%$ (turun sebesar $82 \%$ ), dimana pada penelitian tersebut juga diperoleh rumput laut segar memiliki aktivitas antioksidan yang lebih tinggi. Aktivitas antioksidan tersebut berasal dari kandungan senyawa bioaktif yang terdapat dalam sampel rumput laut itu sendiri.

Proses desalting diduga juga mempengaruhi dimana senyawa bioaktif dalam rendemen ekstrak ikut terbuang ketika penghilangan garam, sehingga persentase rendemen ekstrak menurun. Setelah proses desalting, rendemen yang diperoleh menjadi semakin rendah, yang menunjukkan bahwa ekstrak yang diperoleh mengandung lebih banyak garam 
anorganik yang tidak larut dari pada senyawa yang dapat larut (Suryaningrum, 2006).

\section{Senyawa Fitokimia}

Tabel 1. Hasil uji fitokimia ekstrak metanol rumput laut Kappaphycus alvarezii.

\begin{tabular}{|r|l|l|l|}
\hline No. & \multicolumn{1}{|c|}{$\begin{array}{c}\text { Metabolit } \\
\text { Sekunder }\end{array}$} & \multicolumn{1}{|c|}{ Metode Uji } & \multicolumn{1}{|c|}{$\begin{array}{c}\text { Hasil } \\
\text { Uji }\end{array}$} \\
\hline 1. & Flavonoid & Pereaksi $\mathrm{HCl}$ pekat $+\mathrm{Mg}$ & - \\
\hline & & Pereaksi $\mathrm{H}_{2} \mathrm{SO}_{4} 2 \mathrm{~N}$ & - \\
\hline 2. & Alkaloid & Pereaksi Dragendorff & - \\
\hline 3. & & Pereaksi Wagner & - \\
\hline 4. & $\begin{array}{l}\text { Triterpenoid / } \\
\text { Steroid }\end{array}$ & Pereaksi HCl & - \\
\hline
\end{tabular}

Dari tabel di atas dapat dilihat bahwa senyawa bioaktif seperti flavonoid, alkaloid, saponin, triterpenoid dan steroid tidak terdeteksi dalam ekstrak metanol rumput laut.

Tidak terdeteksinya zat bioaktif pada ekstrak rumput laut dalam penelitian ini diduga akibat pengeringan di bawah sinar matahari. Menurut (Suryaningrum, $d k k ., 2006$ ), panas dan sinar matahari dapat merusak kandungan bioaktif dalam ekstrak sampel. Hal ini didukung oleh hasil penelitian yang diperoleh Sharo, $d k k$. (2013), senyawa fitokimia rumput laut yang dikeringkan dengan cara dijemur dan diekstrak dengan pelarut etanol positif mengandung senyawa triterpenoid dan tidak mengandung senyawa alkaloid, flavonoid, dan steroid. Menurut Robinson (1995) dalam Eleanore (2013) alkaloid memiliki sifat fisik kurang tahan panas.

Kadar garam dalam sampel juga diduga mempengaruhi hasil uji fitokimia. Hal ini disebabkan oleh proses desalting yang tidak maksimal. Teknik desalting yang tidak maksimal tersebut dapat mempengaruhi hasil analisa karena garam dapat bereaksi dengan senyawa-senyawa yang terdapat dalam sampel. Menurut Suryaningrum, $d k k$. (2006) adanya garam anorganik dalam jumlah besar akan memberikan hasil bioassay yang salah.

Pada penelitian yang dilakukan oleh Tanod \& Amelia (2016), aktivitas antioksidan rumput laut yang dikeringkan dengan panas matahari selama 3 hari diperoleh sangat lemah dibanding dengan dikeringkan menggunakan oven selama 1 hari karena suhu oven bersifat lebih stabil dibandingkan dengan suhu sinar matahari yang sangat bervariasi $\left(35-47^{\circ} \mathrm{C}\right)$. Dari penelitian tersebut diduga senyawa fitokimia yang berperan sebagai antioksidan telah rusak karena intensitas cahaya yang tinggi dan waktu radiasi cahaya yang lama.
Kandungan fitokimia yang diperoleh dari penelitian ini juga dipengaruhi oleh jenis rumput laut itu sendiri. Kandungan fitokimia berbeda-beda pada tiap jenis rumput laut. Pada penelitian yang telah dilakukan oleh Maharany, $d k k$. (2017) rumput laut jenis Padina australis lebih banyak mengandung senyawa fitokimia (positif flavonoid, fenol hidrokuinon, triterpenoid, tanin dan saponin) dibandingkan dengan Kappaphycus alvarezii (positif flavonoid, fenol hidrokuinon, dan triterpenoid).

\section{Aktivitas Antioksidan}

Pada penelitian ini diperoleh nilai $\mathrm{IC}_{50}$ dari sampel rumput laut adalah sebesar $163.819,99 \mathrm{ppm}$ dan nilai $\mathrm{IC}_{50}$ kontrol positif Vitamin C adalah sebesar 7,99 ppm (gambar 1).

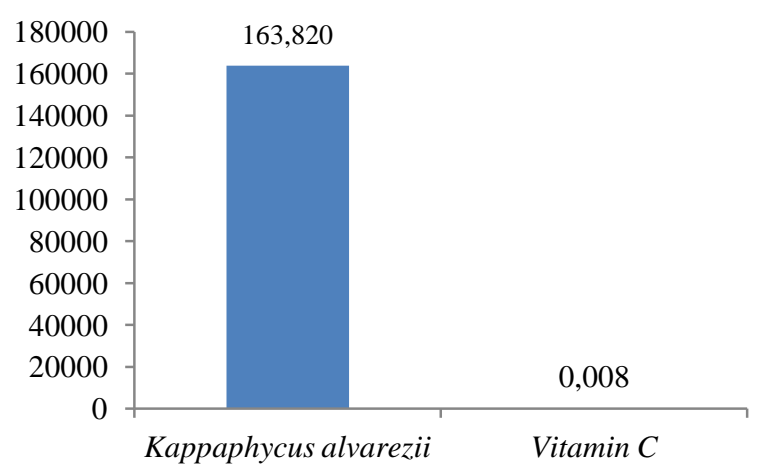

Gambar 1. Aktivitas antioksidan $\mathrm{IC}_{50}$ Kappaphycus alvarezii dan Vitamin $C$.

Kurva daya hambat antioksidan ekstrak metanol rumput laut dan kontrol positif vitamin C terhadap senyawa DPPH dapat dilihat pada gambar 2 dan gambar 3 .

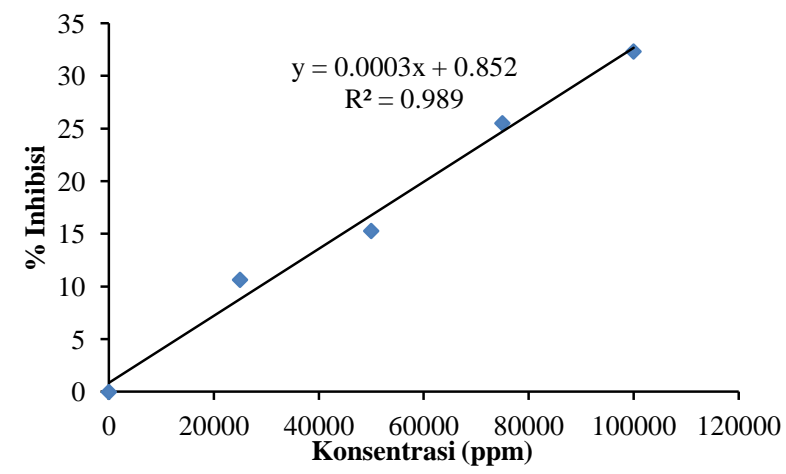

Gambar 2. Kurva daya hambat ekstrak metanol rumput laut Kappaphycus alvarezii terhadap senyawa DPPH.

Menurut Molyneux (2004), semakin kecil nilai $\mathrm{IC}_{50}$ berarti semakin tinggi aktivitas antioksidan. Secara spesifik suatu senyawa dikatakan sebagai antioksidan sangat kuat jika nilai $\mathrm{IC}_{50}$ kurang dari $50 \mathrm{ppm}\left(\mathrm{IC}_{50}<50 \mathrm{ppm}\right)$, kuat $\left(50<\mathrm{IC}_{50}<100 \mathrm{ppm}\right)$, sedang $\left(100<\mathrm{IC}_{50}\right.$ 
$<150 \mathrm{ppm})$, lemah (150 ppm $\left.<\mathrm{IC}_{50}<200 \mathrm{ppm}\right)$, dan sangat lemah $\left.\mathrm{IC}_{50}>200 \mathrm{ppm}\right)$. Dari hasil pengujian ini menunjukkan bahwa sampel rumput laut memiliki aktivitas antioksidan yang sangat lemah karena menunjukkan $\mathrm{IC}_{50}>200 \mathrm{ppm}$ dibandingkan dengan kontrol positif Vitamin $\mathrm{C}$ yang memiliki aktivitas antioksidan yang sangat kuat karena menunjukkan $\mathrm{IC}_{50}<50 \mathrm{ppm}$.

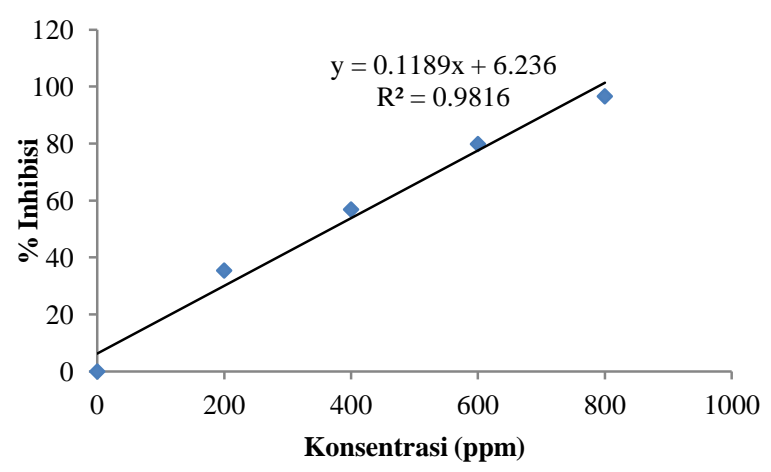

Gambar 3. Kurva daya hambat antioksidan kontrol vitamin $C$ terhadap senyawa DPPH.

Nilai $\mathrm{IC}_{50}$ rumput laut yang diperoleh sangat kecil dibandingkan dengan vitamin $\mathrm{C}$ ini disebabkan karena ekstrak yang diuji masih berupa campuran beberapa senyawa, dan vitamin $\mathrm{C}$ sudah berupa senyawa murni yang bertindak sebagai antioksidan.

Hasil aktivitas antioksidan $\mathrm{IC}_{50}$ yang didapat dari penelitian ini sangat rendah diduga karena adanya pengaruh rumput laut yang diperoleh sudah dalam keadaan kering. Rumput laut tersebut dikeringkan menggunakan panas dan cahaya matahari. Menurut Suryaningrum, $d k k$. (2006) zat bioaktif yang merupakan sumber antioksidan ini mudah rusak bila terkena panas dan cahaya matahari ketika pengeringan.

Menurut Suresh et al. (2007) rumput laut diketahui memiliki kandungan senyawa fenolik. Senyawa fenolik merupakan salah satu kandungan rumput laut yang berperan sebagai antioksidan. Senyawa fenolik merupakan salah satu kandungan rumput laut yang berperan sebagai antioksidan. Ekstraksi pada suhu di atas $60^{\circ} \mathrm{C}$ dapat menurunkan senyawa fenolik pada Kappaphycus alvarezii (Sari dkk., 2013). Ketidakstabilan fenolik pada suhu tinggi tersebut diperkirakan dapat menyebabkan aktivitas antioksidan melemah (Liazid et al, 2007).

Konsentrasi pelarut juga mempengaruhi aktivitas antioksidan sampel. Dari hasil penelitian yang dilakukan oleh Damongilala $d k k$. (2013) antioksidan terbaik didapat dari Eucheuma spinosum segar yang dimaserasi mengguna- kan pelarut metanol dengan konsentrasi $60 \%$. Penelitian yang dilakukan juga oleh Dotulong (2014), kemampuan menghambat radikal bebas DPPH tertinggi pada jenis alga Caulerpa sertularoides, Laurencia tronoi dan Padina australis terdapat pada ekstrak metanol 50\%. Menurut Fathurrachaman (2014) konsentrasi pelarut yang digunakan memiliki polaritas yang berbeda-beda dan berhubungan dengan kandungan metabolit sekunder yang tersaring pada proses ekstraksi. Adanya kandungan metabolit sekunder dapat berpengaruh pada aktivitas antioksidan dari sampel tersebut.

Salah satu senyawa fitokimia yakni flavonoid merupakan senyawa yang mempunyai gugus fenol yang lebih kompleks dengan derajat hidroksilasi yang lebih tinggi. Keberadaan gugus hidroksil pada senyawa fenol dan flavonoid menimbulkan aktivitas antioksidan. Hal ini dapat disebabkan karena atom oksigen pada gugus hidroksil mempunyai pasangan elektron bebas yang cukup untuk menghambat reaktivitas atom reaktif penyusun senyawa radikal bebas (Egwaikhide \& Gimba 2007 dalam Eleanore, 2013).

\section{KESIMPULAN DAN SARAN}

\section{Kesimpulan}

Berdasarkan hasil penelitian ini, maka dapat disimpulkan bahwa:

1. Ekstrak kental rumput laut Kappaphycus alvarezii yang diperoleh adalah sebanyak 12 gram dan rendemen $0,034 \%$.

2. Kandungan fitokimia berupa alkaloid, flavonoid, saponin, triterpenoid dan steroid tidak terdeteksi pada rumput laut Kappaphycus alvarezii ekstrak metanol.

3. Aktivitas antioksidan dengan metode DPPH pada rumput laut Kappaphycus alvarezii ekstrak metanol sangat lemah dimana $\mathrm{IC}_{50}$ $>200$ ppm yakni $163.819,99$ ppm, dimana $\mathrm{IC}_{50}$ merupakan konsentrasi larutan sampel yang mampu mereduksi aktivitas radikal bebas DPPH sebesar 50\%.

\section{Saran}

Berdasarkan hasil penelitian ini maka disarankan bahwa sampel rumput laut tidak dijemur di bawah sinar matahari, karena akan merusak senyawa bioaktif di dalamnya. Selain itu perlu dilakukan ekstraksi dengan menggunakan pelarut, tingkat konsentrasi pelarut dan metode ekstraksi yang berbeda sehingga dapat memperoleh senyawa-senyawa bioaktif dan 
aktivitas antioksidan yang maksimal dari rumput laut Kappaphycus alvarezii agar dapat dimanfaatkan sebagai pangan fungsional.

\section{DAFTAR PUSTAKA}

BPOM. 2001. Peraturan Kepala Badan Pengawas Obat dan Makanan Republik Indonesia Tentang Pengawasan Klaim Dalam Label dan Iklan Pangan Olahan.

Suarni., Yasin, M. 2011. Jagung sebagai Sumber Pangan Fungsional Iptek Tanaman Pangan Vol. 6 No. 1. 2011.

Putranto, U.D. 2015. Pangan Fungsional dari Jamur Tiram. Penyuluhan Jamur Pangan di Desa Argo Peni, Kecamatan Ayah, Kabupaten Kebumen. Universitas Jenderal Soedirman. Purwakarta.

Setyowati, W.A.E., Ariani, S.R.D., Ashadi, Mulyani, B., Rahmawati, C.P. 2014. Skrining Fitokimia dan Identifikasi Komponen Utama Ekstrak Metanol Kulit Durian (Durio zibethinus murr.) Varietas Petruk. Seminar Nasional Kimia dan Pendidikan Kimia VI. Prodi Pendidikan Kimia Jurusan FMIPA FKIP Universitas Surakarta.

Sukesi dan Sirat, W. D. 2012. Antioksidan dalam Bakso Rumput Laut Merah Eucheuma cottonii. Jurusan Kimia, Fakultas Matematika dan Ilmu Pengetahuan Alam, Institut Teknologi Sepuluh November (ITS) Surabaya. Jurnal Sains dan Seni Pomits Vol. 1, No. 1, (2012) 1-4.

Faskalia dan Wibowo, A. M. 2014. Skrining Fitokimia, Uji Aktivitas, Antioksidan dan Uji Sitotoksik Ekstrak Metanol pada Akar dan Kulit Batang Soma (Ploiarium alternifolium). Program Studi Kimia, Fakultas MIPA, Universitas Tanjungpura. Jkk, Tahun 2014, Volum 3(3), Halaman 1-6 ISSN 23031077. Pontianak.

Suryaningrum, D., Wikanta, T. dan Kristiana, H. 2006 Uji Senyawa Antioksidan dari Rumput Laut Halymenia harveyana dan Euchema cottonii. Pascapanen dan Bioteknologi Kelautan dan Perikanan. $1(1): 51-63$

AOAC. 1995. Official Methods of Analysis of The Association of Official Analytical Chemists. Washington.

Harborne, J.B. 1987. Metode Fitokimia, Penuntun Cara Modern Menganalisis. Tumbuhan. Terjemahan Kosasih P dan Iwang SJ., ITB Bandung.

Blois, M.S. 1958. Antioxidant Determinations by the Use of a Stable Free Radical. Natural. 181, 1199-1200.

Maulana. A. 2012. Aktivitas Antioksidan Rumput Laut Euchema spinosum. Skripsi. Departemen Ilmu dan Teknologi Kelautan Fakultas Perikanan dan Ilmu Kelautan Institut Pertanian Bogor. Bogor.

Damar, A.R., M.R.J. Runtuwene dan D. Silvia. 2014. Kandungan Flavonoid dan Aktivitas Antioksidan Total Ekstrak Etanol Daun Kayu Kapur (Melanolepsis multiglandulosa Reinch). Jurnal Ilmiah Farmasi FMIPA UNSRAT, Manado. Vol.3(4):11-21.

Sharo, N.M., Ningsih, R.N., Nasichuddin, A., dan Hanapi, A. 2013. Uji Toksisitas dan Identifikasi Senyawa Ekstrak Alga Merah (Eucheuma cottonii) Terhadap Larva Udang Artemia salina leach. Jurusan
Kimia, Fakultas Sains dan Teknologi UIN Maulana Malik Ibrahim. Alchemy, Vol. 2 No. 3, Hal. 170-177. Malang.

Eleanore, Y. 2013. Analisis Fitokimia dan Aktivitas Antioksidan Ekstrak Daun Sengon (Paraserianthes falcataria (L) Nielsen) Menggunakan Metode DPPH. Skripsi. Departemen Biokimia Fakultas Matematika dan Ilmu Pengetahuan Alam Institut Pertanian Bogor. Bogor.

Tanod, W.A., Amelia, R. 2016. Kandungan Antioksidan Alga Merah Eucheuma Cottonii dengan Metode Pengeringan Yang Berbeda. Jurnal. Sekolah Tinggi Perikanan dan Kelautan (STPL) Palu "Kauderni": Journal Of Fisheries, Marine And Aquatic Science" Volume 1, Nomor 1.

Maharany, F., Nurjanah., Suwandi, R., Anwar, E. dan Hidayat, T. 2017. Kandungan Senyawa Bioaktif Rumput Laut Padina australis dan Eucheuma cottonii Sebagai Bahan Baku Krim Tabir Surya. Departemen Teknologi Hasil Perairan, Fakultas Perikanan Dan Ilmu Kelautan, Institut Pertanian Bogor. JPHP Volume 20 Nomor 1.

Molyneux, P. 2004. The Use Of The Stable Free Radical Diphenylpicryl-Hydrazil (DPPH) For Estimating Antioxidant Activity. Science Technology, 26 (2):211219.

Suresh K.K., Canusan.K., Subba R.P.V (2008). Antioxidant Potential of Solvent Extract Of Kappaphycus alvarezii (Doty) Doty-An Edible Seaweed. Food Chemistry 107, 289-295.

Sari, B.L., Susanti, N., dan Sutanto. 2015. Skrining Fitokimia dan Aktivitas Antioksidan Fraksi Etanol Alga Merah Eucheuma spinosum. Program Studi Farmasi, FMIPA, Universitas Pakuan. Jurnal. Vol. 2 No. 1. Pharm Sci Res ISSN 2407-2354. Bogor.

Liazid, A., Palma, M., Brigui, J., \& Barroso, C. G, 2007, Investigation on phenolic compounds stability during microwave-assisted extraction. Journal Chromatography A, 1140, 29-34.

Damongilala, L., Widjanarko, S.B., Zubaidah, E., Runtuwene, M.R.J. 2013. Antioxidant Activity Against Methanol Extraction of Eucheuma cotonii and Eucheuma. spinosum Collected From North Sulawesi Waters, Indonesia. Food Science and Quality Management. ISSN 2224-6088 (Paper) ISSN 22250557 (Online). Vol.17.

Dotulong, V. 2014. Aktifitas Antioksidan Alga Laut Caulerpa sertularoides, Laurencia tronoi, Padina australis, Isolasi dan Elusidasi Senyawa Aktif Pada Fraksi n-Heksana Laurencia tronoi. Disertasi. Program Studi Ilmu Pertanian Minat Teknologi Hasil Perikanan. Program Pascasarjana Universitas Brawijaya. Malang.

Fathurrachman, D.A. 2014. Pengaruh Konsentrasi Pelarut Terhadap Aktivitas Antioksidan Ekstrak Etanol Daun Sirsak (Annona muricata Linn) Dengan Metode Peredaman Radikal Bebas DPPH. Skripsi. Fakultas Kedokteran dan Ilmun Kesehatan. Program Studi Farmasi.UIN Syarif Hidayatullah. Jakarta.

Gunawan, E.R., Suhendra, D. 2012. Screening dan Analisis Kadar Omega-3 Dari Rumput Laut Pulau Lombok NTB. Program Studi Kimia, Fakultas Matematika dan Ilmu Pengetahuan Alam, Universitas 
Mataram.. Jurnal Molekul, Vol. 7. No. 2. November, 2012:95-104. Mataram.

Richard, D., Kefi, K., Bausero, P., Visioli, F. Poly Unsaturated Fatty Acid as Antioxidants. Laboratory of Micronutrients and Cardiovascular Disease. Pharmacol Res. 2008 Jun;57(6):451-5. 